\title{
Cyber Situational Awareness
}

\section{H. Leopold OVE}

Online publiziert am 4. März 2015

(C) Springer Verlag Wien 2015

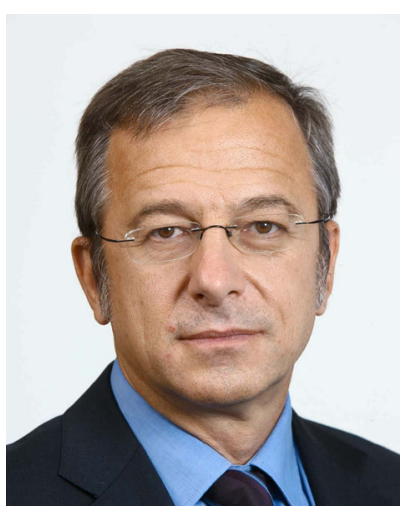

Dipl.-Ing. Helmut Leopold
Die Breitband-basierten Always-on-Kommunikationsplattformen sind der Motor unserer umfassend kollaborativ arbeitenden und vernetzten Erkenntnisgesellschaft und der darauf aufbauenden zukünftigen Innovationsökonomie geworden. Damit ermöglichen wir unsere internationale Wettbewerbsfähigkeit, unseren Wohlstand und unseren gesellschaftlichen Fortschritt.

Informations- und Kommunikationstechnologien

(IKT) haben sich zur zen-

tralen Lebensader für sämtliche Wirtschaftsbranchen und alle Lebensbereiche entwickelt und müssen im gleichen Atemzug wie die Energieversorgung als eine der wesentlichsten kritischen Infrastrukturen unserer Gesellschaft betrachtet werden. Viele unserer Zukunftsfragen wie Energie, Umwelt, Verkehr, Gesundheit, Sicherheit und schließlich unser einfaches Zusammenleben werden wesentlich durch den Einsatz moderner IKT bestimmt. Die aktuelle Entwicklung der vollständigen Vernetzung unserer Maschinen zu Cyber Physical Systems (CPS) als auch die Verlagerung unserer Daten in die Cloud und die sie begleitenden virtuellen Dienstangebote markieren den nächsten Schritt der weltweiten Breitbandvernetzung mit ihren innovativen und wirtschaftlichen Aspekten.

Damit haben wir als Gesellschaft aber auch eine enorme Abhängigkeit einer funktionierenden IKT-Infrastruktur erreicht. Der Funktionsausfall von einzelnen Systemen kann zu beträchtlichen Systemstörungen durch Kaskadeneffekte führen und entsprechenden wirtschaftlichen Schaden für Unternehmen, aber auch ganze Staaten verursachen.

Die IKT-Infrastrukturen haben zudem eine solch hohe Funktionsvielfalt und ein Maß an Komplexität erreicht, so dass Verfügbarkeit und vor allem auch Sicherheitsaspekte nicht mehr im vollen Umfang von einzelnen Unternehmen oder auch von einzelnen staatlichen Organisationen alleine beherrscht werden können. Cyber Incidents (durch Fehlfunktionen oder unbeabsichtigtes Fehlverhalten) oder auch Cyber-Attacken (aus wirtschaftlichen oder politisch begründeten Motiven) haben ebenfalls ein Ausmaß an Komplexität erreicht, welches entsprechende Gegenstrategien vor große Herausforderungen stellt.

Dies ist umso mehr eine Herausforderung, als sich auch die Gefahrenlage im Cyberspace über die letzten Jahre mit der gleichen rasanten Geschwindigkeit potenzierte, wie neue Dienstleistungen und Werkzeuge das Internet bereicherten und nachhaltig veränderten. Vor dem Hintergrund immer raffinierterer und technologisch ausgereifterer Angriffsarsenale für Cyber-Kriminalität, Cyber-Krieg und Cyber-Spionage ist jedes fortschrittliche Land angehalten, in einer Art Wettrüsten und im permanenten Wettlauf mit potentiellen Angreifern geeignete Gegenstrategien zur Sicherung und Erhaltung seiner kritischen Infrastrukturen zu entwickeln und umzusetzen.

Wir werden zukünftig Systeme nicht mehr alleine dadurch schützen können, einen unerlaubten „Zugriff" zu verhindern, wie durch Firewalls und Virenschutz, sondern es braucht neue Funktionen, mit denen Cyber Incidents frühzeitig entdeckt, Risiken und deren potentiellen Auswirkungen beurteilt und Gegenmaßnahmen vorrausschauend vorbereitet werden können. Es geht somit darum, ein wesentlich besseres Lageverständnis im Cyberspace unserer vernetzten IKT-Systeme zu etablieren.

Ein gutes Lageverständnis baut nun auf zwei wesentlichen Pfeilern auf:

(i) Einerseits auf laufende Zustandsinformationen in Echtzeit wie Systemverhalten, Cyber-Attacken und Angriffsvektoren und

(ii) andererseits, nachdem wir es mit einem Zusammenspiel vieler Dienstleistungserbringer zu tun haben, auf einem vertrauenswürdigen Informationsaustausch.

Um diesen Themenkomplex grundlegend zu erörtern, wurde als Ergebnis des Projektes "CAIS Cyber Attack Information System" (2011-2013) im Kontext des österreichischen Sicherheitsforschungsprogramms KIRAS für eine umfassende Dokumentation der aktuellsten Entwicklungen in diesem Bereich ein eigenes Buch konzipiert.

Dieses Werk mit dem Titel „Cyber Attack Information System" erschien Ende März im Springer-Verlag. Darin werden die grundsätzlichen Strukturen für Lagebildprozesse, für ein Cyberabwehrzentrum, für Angriffserkennung und Auswirkungssimulation erörtert. Das vorliegende Buch berichtet über die im Projekt erzielten Ergebnisse zur Stärkung der Widerstandfähigkeit kritischer Infrastrukturen gegenüber zukünftigen Cyber-Angriffen und gibt Empfehlungen für den Aufbau eines Cyberlagezentrums in Österreich. Nähere Informationen finden Sie in der Rubrik "Bücher" auf Seite a 10 dieser Ausgabe. Die weitere wesentliche Thematik des "Trusted Information Sharing" wird in einem eigenen Projekt "Cyber Incident Information Sharing (CIIS)" (2013-2015), ebenfalls unterstützt durch das nationale Sicherheitsforschungsprogramm KIRAS, bearbeitet.

Der aktuelle Themenschwerpunkt in der vorliegenden e\&i-Ausgabe greift nun diese besondere Thematik der "Cyber Situational Awareness" auf und diskutiert einzelne Spezialbereiche in diesem Kontext. Die folgenden Seiten geben Interessierten nicht nur Einblick in die hoch komplexe und brandaktuelle Materie, von der wir alle betroffen sind, sondern zeigen auch, dass das erwähnte Buch als Folge eines nationalen Forschungsprojekts zwar auf Österreich ausgerichtet ist, die Forschung im Bereich "Situational Awareness" jedoch auch über Österreich hinaus von hoher Bedeutung ist, wie die nachfolgenden Seiten eindrucksvoll belegen.

Leopold, Helmut, Digital Safety \& Security Department, AIT Austrian Institute of Technology, Donau-City-Straße 1, 1220, Wien, Österreich

(E-Mail: helmut.leopold@ait.ac.at) 
Der Artikel von Ivo Friedberg et al. „Cyber situational awareness through network anomaly detection: state of the art and new approaches" beschäftigt sich mit den neuesten Entwicklungen der Anomalieerkennung als einen der wichtigsten Bausteine einer wirksamen Abwehr von Cyber-Attacken und Erkennung von durch Fehlfunktionen hervorgerufener Cyber Incidents.

Der Beitrag von Frank Fransen et al. „Cyber security information exchange to gain insight into the effects of cyber threats and incidents" betont einerseits die unbedingte Notwendigkeit einer vertrauensvollen Informationsverteilung und beschreibt andererseits, welche Art von Information zwischen den beteiligten Organisationen ausgetauscht werden soll.

Das Paper von David Sutton „Trusted information sharing for cyber situational awareness" widmet sich der Thematik, wie beim Informationsaustausch zwischen unterschiedlichen Organisationen Vertrauen hergestellt und laufend erhalten werden kann.

Der Beitrag von Helmut Kaufmann et al. "A structural design for a pan-European warning system for critical infrastructures" fasst das Konzept des EU-Projektes ECOSSIAN zusammen, welches zum Ziel hat, eine prototypische Implementierung eines solchen modernen Cyber-Informationssystems zu realisieren, bei der Informationssammlung und Verteilung zwischen Organisationen das bestimmende Element sind.

Und schließlich erörtert der Artikel von Noor-ul-hassan Shirazi et al. "A framework for resilience management in the cloud", als ein Ergebnis des EU-Projektes SECCRIT, wie in zukünftigen verteilten und virtuellen Cloud-basierten IT-Architekturen die Widerstandsfähigkeit solcher IT-Systeme gegenüber Cyber-Attacken als auch Cyber Incidents durch geeignete Funktionen und Architekturen sichergestellt werden kann.

Wir hoffen, Ihnen damit einen interessanten Einblick in die aktuelle technologische Entwicklung dieses neuen und immer wichtiger werdenden Bereichs der IKT-Entwicklung gegeben zu haben und wünschen viel Spaß bei der Lektüre der nachfolgenden Beiträge.

\section{Cyber situational awareness}

Broadband-based always-on communications platforms have become the main driver of our collaborative and interconnected knowledge society and of the future innovation economy based thereupon. They enable our international competitiveness, our prosperity and social progress. Thus, information and communication technologies (ICT) play a vital role for a great number of business areas and spheres of life and have to be considered in the same way as energy supply; i.e. ICT systems and networks became one of the most relevant critical infrastructures of our society.

Most of our future challenges like energy, environment, traffic, health, security and ultimately our simple coexistence are considerably influenced by the use of state-of-the-art information and communication technologies. The current development of our fully interconnected machines towards Cyber Physical Systems (CPS), the transfer of our data and the relocation of our virtual service offerings to the cloud mark a further significant step in the global broadband networking process along with its innovative and economic aspects.

At the same time, however, we - as a society - have reached a high level of dependency on properly functioning ICT infrastructures. The malfunction of single systems can result in a cascade effect, leading to considerable system failures, which in turn can have corresponding economic repercussions on single companies or even on whole nations. Furthermore, ICT infrastructures have also reached such a high level of functionality and complexity that their availability and security aspects are no longer under the sole control of single companies or of single national organizations. Cyber incidents (due to malfunctions or unintended human errors) as well as cyber attacks (due to business reasons or political motivations) have also reached such a high degree of complexity that corresponding counter-strategies pose unprecedented challenges.

The situation is all the more challenging as cyberspace threats have increased over recent years with the same sheer rapidity, with which new services and tools are enriching and permanently changing the Internet. Against the backdrop of increasingly sophisticated and technologically advanced cyber-warfare (cyber crime, cyber war, cyber espionage), every progressive country is required to develop and implement a counter-strategy based on a sort of arms race, i.e. a constant race against potential attackers, with a view to safeguarding and maintaining its critical infrastructures.

In the future, we will no longer be in a position to protect our systems by simply preventing unauthorized access via firewalls or virus protection but we will require new functionalities to be able to detect cyber incidents early on, assess potential risks and related negative effects and put in place corresponding preventive counter-measures. Thus, the challenge is to achieve a better situational awareness in the cyberspace of our interconnected ICT systems.

Good situational awareness builds upon two main pillars:

(i) first, on providing ongoing status information in real time such as system behavior, cyber attacks and attack vectors;

(ii) and, secondly, on a trustworthy exchange of information as we are dealing with a great number of interacting service providers.

In order to discuss this complex issue comprehensively, a book was conceived as a result of the "CAIS Cyber Attack Information System" project (2011-2013) within the framework of the Austrian security research program KIRAS to provide comprehensive information about the latest developments in this area. This book, entitled "Cyber Attack Information System", was first published at the end of March by the Springer-Verlag publishing company. The book explains the basic structures needed for a situational awareness process, a cyber defense center as well as for attack detection and impact simulation mechanisms. In addition, the book reports on the results achieved in strengthening critical infrastructure's resilience to future cyber attacks and provides valuable advice for the creation of a cyber situation centre in Austria. More detailed information in this regard can be found under the heading "Bücher" on page a 10 of this special edition. The other relevant topic of "Trusted Information Sharing" will be dealt with in a separated project known as "Cyber Incident Information Sharing (CIIS)" (2013-2015), which is also supported by the national security research program KIRAS.

The main focus of this e\&i edition is on "Cyber situational awareness" and seeks to discuss specific areas in this context. The following pages do not only give valuable insights into highly complex and topical issues that affect us all. They also impressively demonstrate 
that, even if the above-mentioned book is the result of a national research project and therefore mainly centered upon Austria, research in the area of situational awareness plays an important role also beyond Austria's borders.

The article by Ivo Friedberg et al. "Cyber situational awareness through network anomaly detection: state-of-the-art and new approaches" deals with the latest developments in the area of anomaly detection as one of the most important building blocks of effective prevention of cyber attacks and detection of cyber incidents caused by malfunctions.

The contribution of Frank Fransen et al. "Cyber security information exchange to gain insight into the effects of cyber threats and incidents" stresses the absolute necessity of a trustworthy information sharing system, while describing the types of information that should be exchanged between the organizations involved.

The paper by David Sutton "Trusted information sharing for cyber situational awareness" focuses on how a basis of mutual trust can be established and maintained on an ongoing basis when information is exchanged between different organizations.
The contribution of Helmut Kaufmann et al. "A structural design for a pan-European warning system for critical infrastructures" summarizes the concept behind the ECOSSIAN EU project, whose main objective is the prototypical implementation of such a modern cyber information system, where information collection and information sharing between different organizations are the key determining factors.

And last but not least, the article by Noor-ul-hassan Shirazi et al. "A framework for resilience management in the cloud" explains, as one of the results of the EU project SECCRIT, how IT systems' resilience to both cyber attacks and cyber incidents in future distributed and virtual cloud-based IT architectures can be effectively safeguarded through appropriate functionalities and architectures.

We hope we have provided you with compelling insights into the current technological developments of this new and increasingly important area of ICT and wish you pleasant reading.

\section{Laufende Projekte im Kontext von cyber situa- tional awareness/Current projects in the context of cyber situational awareness}

\begin{tabular}{llll}
\hline Projektname/ & Förderprogramm/ & Webadresse/Web & Logo \\
Project name & Funding & address & \\
& programme & & \\
& & &
\end{tabular}

CAIS - Cyber Attack
Information System

CIIS - Cyber Incident

Information Sharing

ECOSSIAN - European

COntrol System Security

Incident Analysis

Network

PRECYSE - Prevention, protection and REaction to $\mathbf{C Y b e r}$ attack $\mathbf{S}$ to critical infrastructurEs

SECCRIT - SEcure Cloud computing for CRitical infrastructure IT
KIRAS national

http://www.ait.ac.at/ciis

Cils

EU FP7

Ecossian

EU FP7

https://ssl6.ovh.net/ precyse

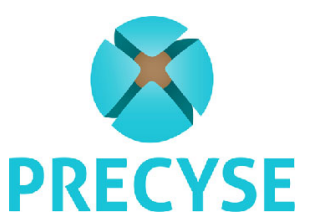

EU FP7

http://www.ait.ac.at/seccrit

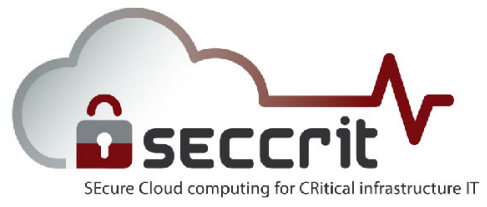




\section{Aktuelle Förderprogramme im Kontext von Cyber Situational Awareness/Current funding programmes in the context of cyber situational awareness}

\section{Österreichisches Sicherheitsforschungsprogramm KIRAS}

Das Österreichische Sicherheitsforschungsprogramm KIRAS ist ein nationales Programm zur Förderung der Sicherheitsforschung in Österreich. KIRAS unterstützt nationale Forschungsvorhaben mit dem Ziel der Erhöhung der Sicherheit Österreichs und seiner Bevölkerung (http://www.kiras.at/das-programm/grundlagen-von-kiras).

\section{Austrian security research programme KIRAS}

The Austrian security research programme KIRAS is a national programme to promote safety research in Austria. KIRAS supports national research projects with the aim of increasing the security of Austria and its people (http://www.kiras.at/das-programm/ grundlagen-von-kiras).

\section{Horizon 2020: Das EU-Programm für Forschung und Innovati-} on

Horizon 2020 ist das weltweit größte, transnationale Programm für Forschung und Innovation mit der Laufzeit 2014 bis 2020 und ist das Nachfolgeprogramm von FP7. Horizon bildet einen gemeinsamen Rahmen für drei Ziele: wissenschaftliche Exzellenz, Wettbewerbsfähigkeit und Marktführerschaft sowie große gesellschaftliche Herausforderungen. Einer der Themenschwerpunkte dieses Programms beschäftigt sich mit der Sicherheit der Gesellschaft (http://ec.europa.eu/programmes/horizon2020/h2020-sections).

\section{Horizon 2020: the EU programme for research and innovation}

Horizon 2020 is the world's largest transnational program for research and innovation with the term 2014 to 2020 . H2020 follows the previous FP7 research programme. Horizon provides a common framework for three goals: academic excellence, competitiveness and market leadership as well as major societal challenges. One of the focus areas is "Secure societies - Protection freedom and security of Europe and its citizens" (http://ec.europa.eu/programmes/ horizon2020/h2020-sections).

\section{Innovationsplattform Inno4Sec}

Bedarfsträgerorientiertes Innovationskonzept für die Sicherheitsforschung

Inno4Sec zielt auf die Entwicklung eines bedarfsorientierten Innovationskonzeptes für die österreichische Sicherheitsforschung ab. Im Rahmen einer Studie wurden in engem Dialog mit den Bedarfsträgern und in optimierter Vernetzung mit der entwickelnden Industrie Forschungsansätze und Lösungen zur Verbesserung der Zusammenarbeit zwischen Forschung und Industrie, zur Erhöhung der Effizienz im Innovationssystem und damit zur Verbesserung der Resilienz gegenüber Systembedrohungen erarbeitet (http://www.ait.ac.at/inno4sec).

\section{Innovation platform Inno4Sec}

Demand carrier-oriented innovation approach to security research

Inno4Sec aims at the development of a demand-driven innovation concept for the Austrian security research. In a study in close consultation with the demand carriers and optimized networking with the evolving industry research, approaches and solutions to improve the cooperation between research and industry, to increase the efficiency of the innovation system and thus improve the resilience to system threats, were carried out (http://www.ait.ac.at/inno4sec) 